\title{
The electrical axis of the heart in patients with atrial fibrillation before and after radiofrequency ablation
}

\author{
S. V. Rybchynskyi ${ }^{1}$, M. S. Brynza ${ }^{1}$, D. Ye. Volkov², M. I. Yabluchanskyi ${ }^{1}$ \\ ${ }^{1}$ V. N. Karazin Kharkiv National University, Ukraine, ${ }^{2}$ SI "Zaitsev V. T. Institute of General and Urgent Surgery NAMS of Ukraine”, Kharkiv
}

Aim - to study changes of the electrical axis of the heart in patients with atrial fibrillation before and after radiofrequency ablation with pulmonary veins isolation.

Materials and methods. Data from the study of heart electrical axis (HEA) position in 40 patients (24 men and 16 women) with atrial fibrillation before and during acute postoperative period (3-7 days) after performed radiofrequency ablation with pulmonary vein isolation (RFA PVI) were presented. The values of vector $\alpha$ angle of HEA ( $\alpha F Q R S)$ and its projections to the frontal ( $\alpha Q R S$ $\max \mathrm{F}$ ), the sagittal ( $\mathrm{aQRS} \max \mathrm{Si})$ and the horizontal plane ( $\mathrm{QQRS}$ max $\mathrm{H}$ ) were determined for the averaged complex in 5 seconds. Patients were divided into 3 groups: the group 1 - normal position of HEA $\alpha=30-70(n=10)$, the group 2 - deviations of HEA to the left $\alpha<30(n=23)$ and the group 3 - deviations of HEA to the right $-\alpha>70(n=7)$. The analysis of the changes reliability after the operation was carried out using the Wilcoxon test.

Results. It has been established that the initially bimodal distribution of resultant vector with maxima in the groups 1 and 2 changed to a unimodal asymmetric with a maximum value displacement to the group 1 region. The changes in $\mathrm{FF}$ QRS max projections on a plane yielded little information. There was a change in the resultant $\mathrm{aF}$ QRS in all patients after RFA PVI and in one third (32.5\%) of the patients normalizing of the HEA position took place, and in $5 \%$ - an increase in $\mathrm{FF}$ QRS with the transition to the group 3 .

Conclusions. A further study of aF QRS changes, a comparison of aF QRS and the atrial vector are required.
Key words: atrial fibrillation, catheter ablation.

\section{Zaporozhye} medical journal 2018; 20 (5), 615-618 DOI: 10.14739/2310-1210 2018.5.141643

E-mail: m.yabluchansky@ karazin.ua

\section{Електрична вісь серця в пацієнтів із фібрияяцією передсердь до та після перенесеної радіочастотної абляції}

\section{С. В. Рибчинський, М. С. Бринза, А. Є. Волков, М. І. Яблучанський}

Мета роботи - вивчити зміни електричної осі серця в пацієнтів із фібриляцією передсердь до і після радіочастотної абляції з ізоляцією легеневих вен.

Матеріали та методи. Наведені дані вивчення зміни положення електричної осі серця (EBC) у 40 пацієнтів (24 чоловіки та 16 жінок) з фібриляцією передсердь до і в гострий післяопераційний період (3-7 доба) після перенесеної радіочастотної абляції 3 ізоляцією легеневих вен (РЧА ЛВ). Встановлювали значення вектора кута $\alpha \mathrm{EBC}(\alpha \mathrm{F} Q \mathrm{RS}$ ) і його проекцій на фронтальну ( $\alpha \mathrm{QRS}$ $\max \mathrm{F}$ ), сагітальну (aQRS max Si) і горизонтальну площини (aQRS max H) за усередненим комплексом за 5 секунд. Пацієнтів поділили на 3 групи: група 1 - нормального положення $\mathrm{EBC} \alpha=30-70(n=10)$, група $2-$ відхилення $\mathrm{EBC}$ вліво $\alpha<30(n=23)$, група 3 - відхилення ЕВС вправо - $\alpha>70(n=7)$. Аналіз вірогідності змін після операції виконали з використанням тесту Вілкоксона.

Результати. Встановлено, що спочатку бімодальний розподіл результуючого вектора з максимумами у групах 1 i 2 змінюється на одномодальний асиметричний зі зміщенням максимуму значень в область групи 1. Зміни проекцій aF QRS max на площині були малоінформативними. Після PЧA ЛB у всіх пацієнтів відбувається зміна результуючого aF QRS, у третини $(32,5$ \%) пацієнтів відбувається нормалізація EBC, у 5 \% - збільшення aF QRS із переходом у групу 3.

Висновки. Потрібне наступне дослідження зміни aF QRS, порівняння змін кута aF QRS і передсердного вектора.

\section{Электрическая ось сердца у пациентов с фибримяцией предсердий до и после перенесенной радиочастотной аблации}

\section{С. В. Рыбчинский, М. С. Брынза, А. Е. Волков, Н. И. Яблучанский}

Цель работы - изучить изменения электрической оси сердца у пациентов с фибрилляцией предсердий до и после радиочастотной аблации с изоляцией легочных вен.

Материалы и методы. Представлены данные изучения изменения положения электрической оси сердца (ЭОС) у 40 пациентов (24 мужчины и 16 женщин) с фибрилляцией предсердий до и в острый послеоперационный период (3-7 сутки) после перенесенной радиочастотной аблации с изоляцией легочных вен (РЧА ЛВ). Определяли значения вектора угла а ЭOC ( $\mathrm{aF}$ QRS) и его проекций на фронтальную ( $\mathrm{aQRS} \max \mathrm{F}$ ), сагиттальную ( $\mathrm{aQRS} \max \mathrm{Si}$ ) и горизонтальную плоскости ( $\alpha Q R S$ max H) по усредненному комплексу за 5 секунд. Пациенты разделены на 3 группы: группа 1 - нормального положения ЭОС $\alpha=30-70(n=10)$, группа 2 - отклонения ЭОС влево $\alpha<30(n=23)$, группа 3 - отклонения ЭОС вправо $-\alpha>70$ $(\mathrm{n}=7)$. Анализ достоверности изменений после операции проводили с использованием теста Вилкоксона.

Результаты. Установлено, что изначально бимодальное распределение результирующего вектора с максимумами в группах 1 и 2 изменяется на одномодальное ассиметричное со смещением максимума значений в область группы 1. Изменения проекций aF QRS max на плоскости были малоинформативными. После РЧА ЛВ у всех пациентов происходит изменение результирующего $\mathrm{aF}$ QRS, у трети (32,5 \%) пациентов происходит нормализация ЭОС, у 5 \% - увеличение $\mathrm{aF}$ QRS с переходом в группу 3.
Киючові слова: фібрияяція переасераь, радіочастотна абляція.

\section{Запорізький} медичний журнал. - 2018. -

T. 20, № 5(110). C. $615-618$ Выводы. Требуется дальнейшее исследование изменения $\mathrm{aF}$ QRS, сравнение изменений угла aF QRS и предсердного вектора. 


\section{Introduction}

Atrial fibrillation (AF) - one of the most common arrhythmias in clinical practice, it is a significant cause of strokes, heart failure and cardiovascular death in the world [1-3]. The leading method of AF treatment in view of conservative therapy ineffectiveness is radiofrequency catheter ablation (RFA) with the pulmonary veins isolation (PVI) [2,4].

One of the RFA PVI effects is the change in the heart electrical axis (HEA), which, however, has been studied extremely little, mainly relating only atria [5-9].

\section{Aim}

To study changes of the electrical axis of the heart in patients with atrial fibrillation before and after radiofrequency ablation with pulmonary veins isolation.

\section{Materials and methods}

40 patients aged $58.0 \pm 9.7$ years $(M \pm s d)(16-$ female, 24 - male) with AF were examined in the Department of Ultrasound and Instrumental Diagnostics with Miniinvasive Interventions of SI "Zaycev V. T. Institute of General and Urgent Surgery of NAMS of Ukraine". All patients had been undergone RFA PVI in period from 2015 to 2017.

The $\alpha$ angle values were measured in projections to the frontal ( $a Q R S$ max $F$ ), the sagittal ( $a Q R S$ max $\mathrm{Si})$ and the horizontal plane (aQRS max $H$ ), as well as the resulting vector of HEA ( $\alpha F$ QRS) before and during the acute postoperative period (3-7 days) after RFAPVI on the averaged complex for a period of 5 seconds in 12 leads of the standard ECG, recorded on the computer cardiograph of HAI Medica "Cardiolab +" (Kharkiv, Ukraine).

According to the HEA position depending on the angle a value, 3 groups of patients were identified: the group 1 normal HEA position $\alpha=30-70(n=10)$, the group 2 - left HEA deviation $\alpha<30(n=23)$ and the group 3 - deviation of HEA to the right $-\alpha>70(n=7)$.

In the generated database in Microsoft Excel, Statistica 10 , the obtained data were processed in programs using standard statistical procedures. Calculations for nonparametric data: absolute $-n$ (number) and $p(\%$, units). Parametric data mean (M, units) and standard deviation (sd, units). The analysis of distribution was performed using asymmetry, kurtosis and median ( $\gamma$, units). A statistical significance analysis of the differences in a angle changes before and after RFAPVI was performed using the Wilcoxon test, the significance level was set at $P<0.05$.

\section{Results and discussion}

The $\alpha F$ QRS angle distribution among all patients was bimodal with maxima in the groups 1 and 2 before performing RFA PVI (Fig. 1). After RFA PVI the aF QRS angle distribution became asymmetric unimodal (asymmetry $Y=-0.79$, excess $Y=-0.2$ ) with the displacement of the values peak to the right, into the region of the group 2 (change of median from 25.5 to 38) (Figure 1). The median value of $\alpha F$ QRS angle in the groups 1 and 3 was slightly decreased, but in the group 2 it was significantly reduced.

Distributions of aQRS max angle for the frontal (A), horizontal $(\mathrm{B})$ and sagittal $(\mathrm{C})$ planes projections are shown in Fig. 2. In each plane the original form of aQRS max values distribution was preserved. In the frontal and horizontal planes there was a decrease in the median value for each group. In the sagittal plane the order of medians positions before RFA on the graph was different from the other planes: the group 3 has a more left-handed position than the groups 2 and 1, and medians positions changed after RFA to the ordinary order in the other planes - for the groups 2, 1 and 3 .

In the frontal and horizontal planes the median value for each group decreased; in the sagittal plane the decrease occurred in the group 1 and increase - in the groups 2 and 3 .

Statistically significant changes in the $\mathrm{aF}$ QRS angle and its projections on planes were revealed in the horizontal plane in the general group with a change in the mean $\alpha F$ QRS towards the HEA deviation to the left (from $36.02^{\circ}$ to $\left.30.53^{\circ}\right)(P<0.05)$. Similarly, in the horizontal plane a marked decrease in the mean $\mathrm{aF}$ QRS angle value in the group 2 (from $21.21^{\circ}$ to $8.78^{\circ}$ ) was statistically significant $(P<0.05)$.
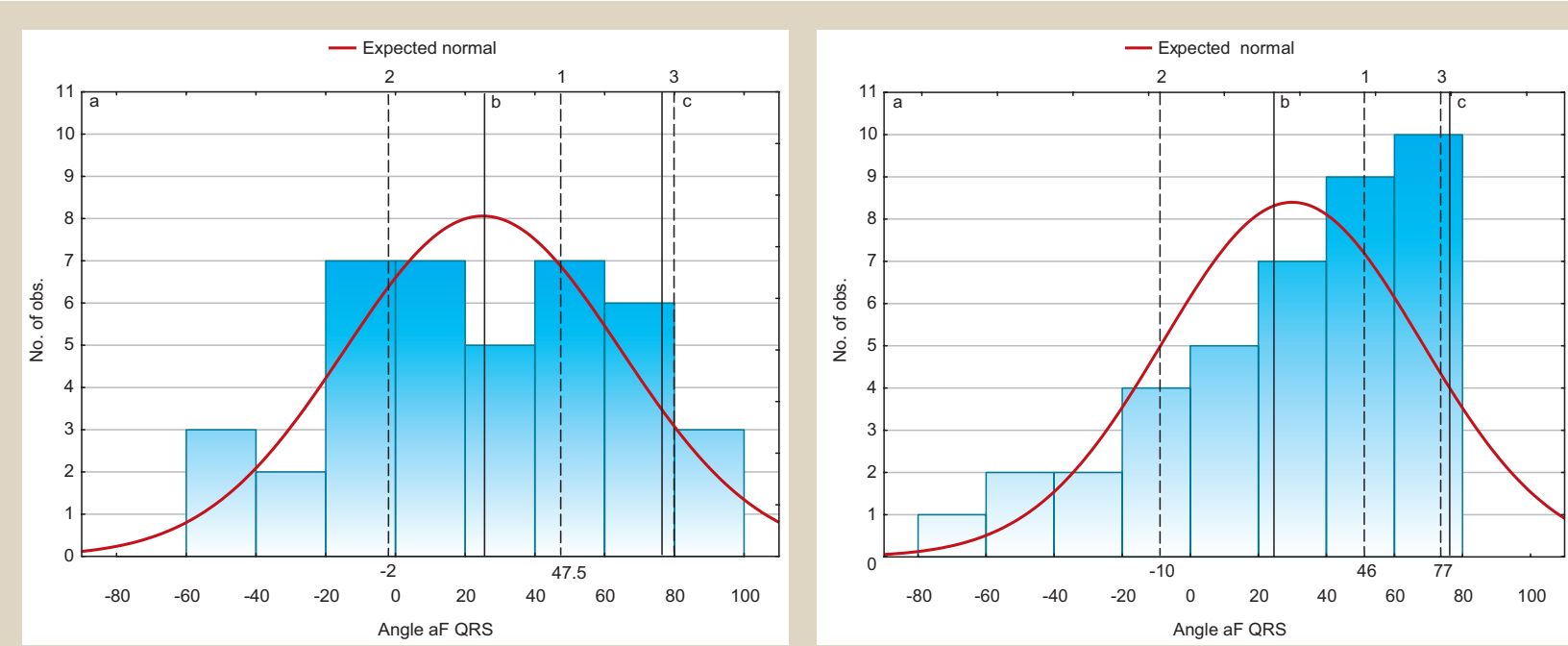

Fig. 1. aF QRS angles distribution before (on the left) and after (on the right) performing RFA PVI in the groups 1 (b), 2 (a), 3 (c), median values of angles in each group $(1,2,3$, respectively). 
In the sagittal plane there was an increase in the mean $\mathrm{aF}$ QRS in the general group (from $40.97^{\circ}$ to $\left.47.53^{\circ}\right)(P<0.05)$. In the other planes no statistically significant changes were detected.

Data on transitions of patients from one to another group after RFA PVI are presented in Table. 1.
Before RFA PVI the group 1 accounted $25.0 \%$, the group $2-57.5 \%$ and the group $3-17.5 \%$ of patients. After RFA PVI in the group 1 was $52.5 \%$, in the group $2-35.0 \%$, in the group $3-12.5 \%$ of patients. In $37.5 \%$ $(n=15)$ of patients $\alpha$ angle deviation with change of group after RFA occurred. At the same time, $32.5 \%(n=13)$ of

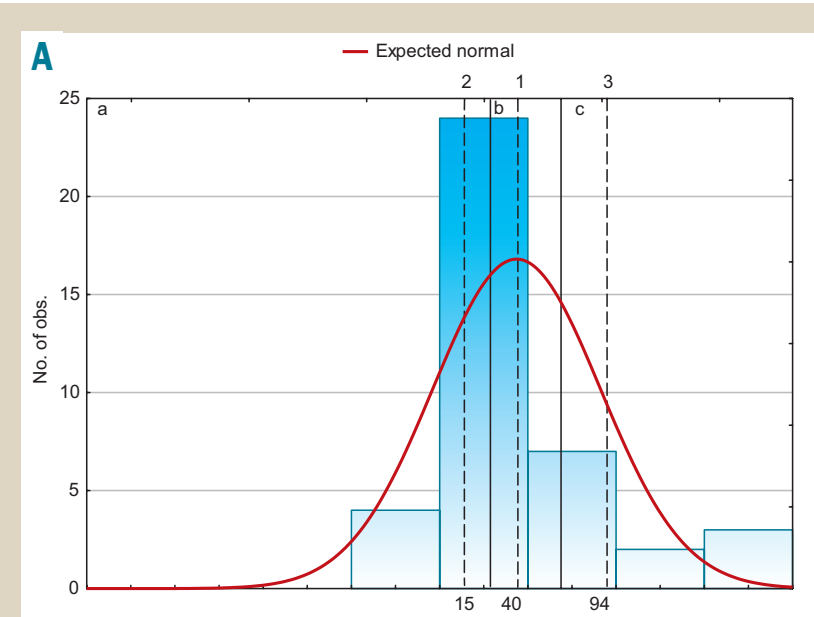

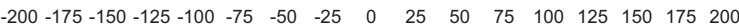
Angel aQRS max $F$

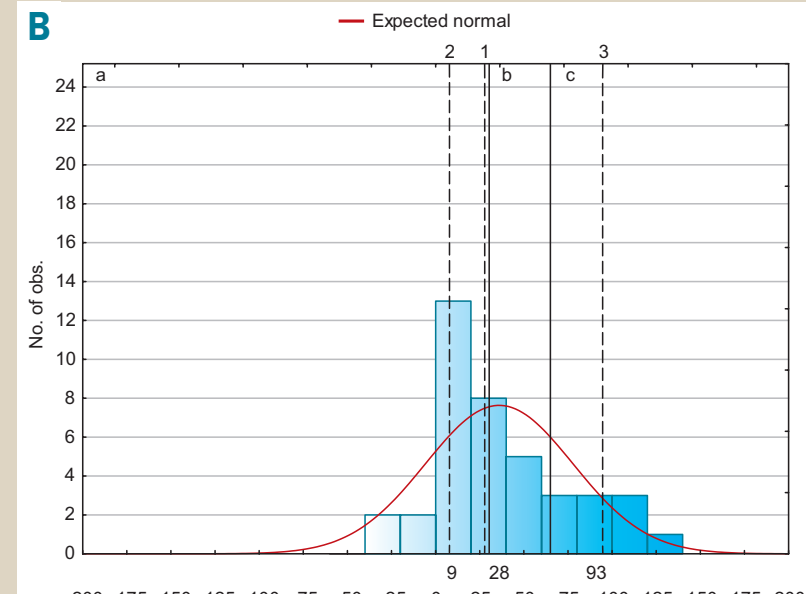

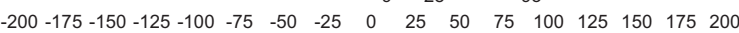
Angle aQRS max $\mathrm{H}$

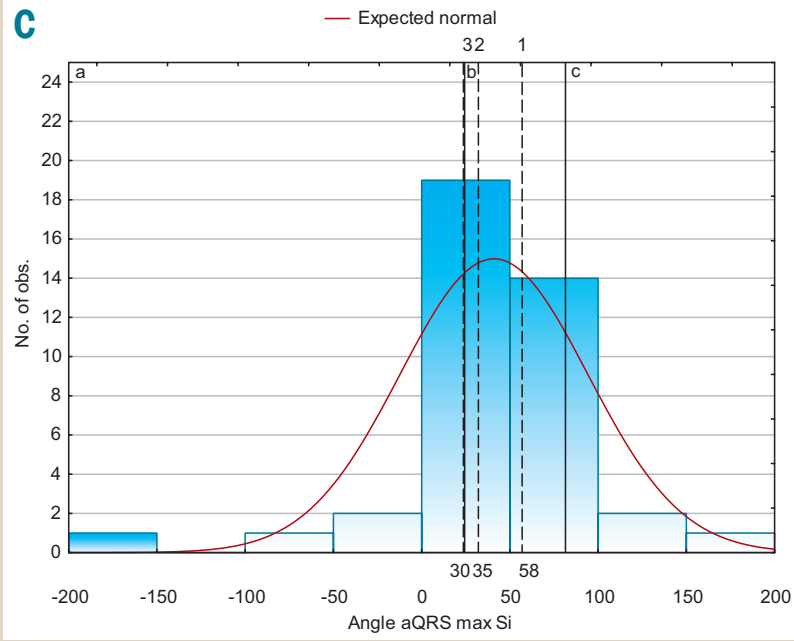

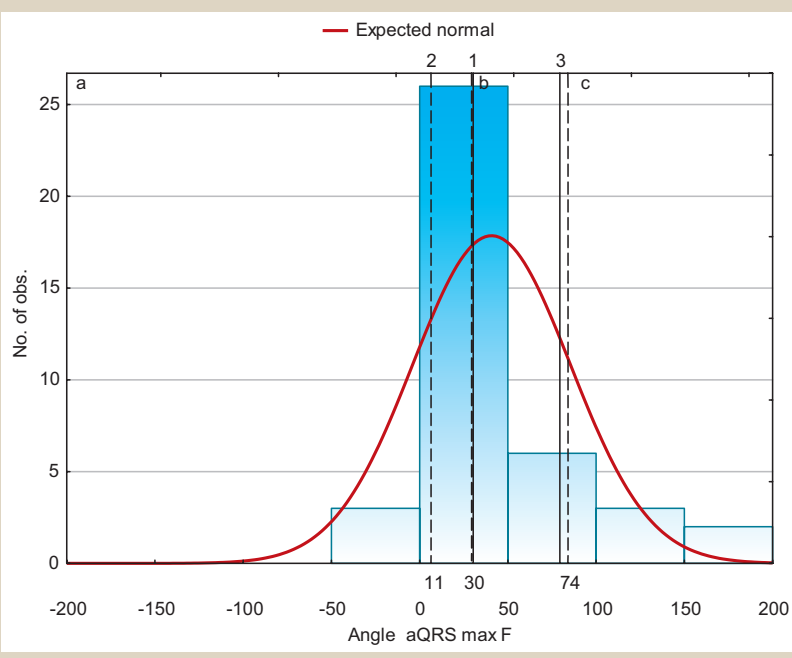

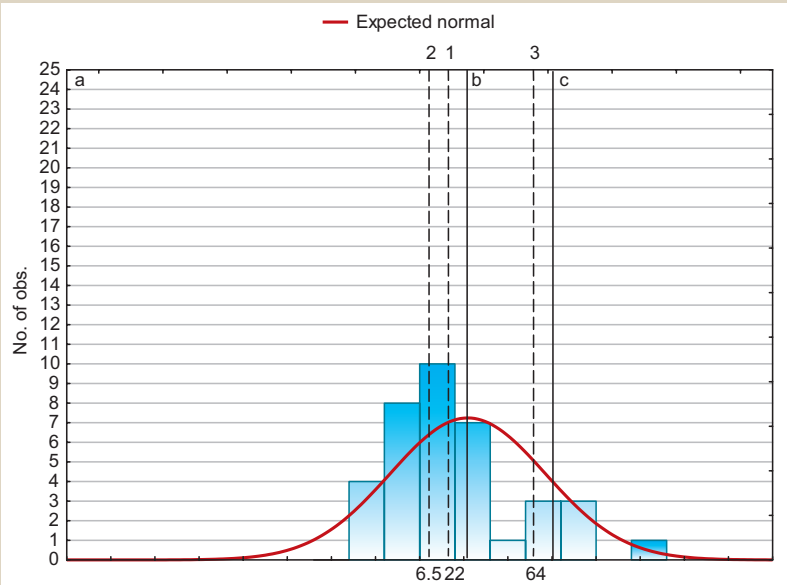

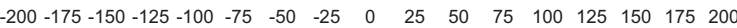
Angle aQRS max $\mathrm{H}$

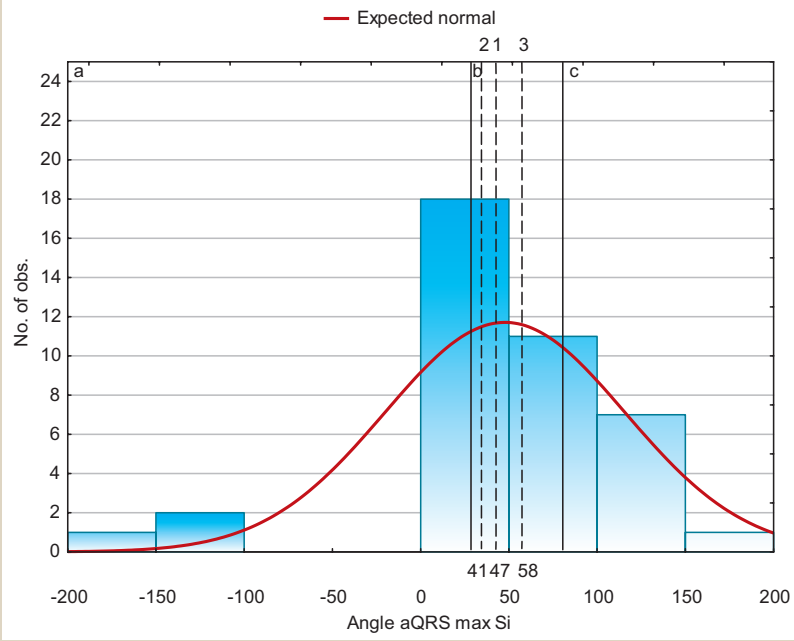

Fig. 2. Distributions of aQRS max angle $F(A), a Q R S$ max angle $H(B), a Q R S$ max angle Si (C) before (on the left) and after (on the right) RFA PVI in the groups 1 (b), 2 (a), 3 (c), median values of angles in each group (1,2, 3, respectively). 
Table 1. Number of patients in groups before and after RFA PVI with display of their transitions from one to another group

\begin{tabular}{l|l|l|l|l|l}
$\begin{array}{l}\text { Groups } \\
\text { of patients }\end{array}$ & $\begin{array}{l}\text { Number } \\
\text { of patients } \\
\text { before } \\
\text { ablation }\end{array}$ & $\begin{array}{l}\text { Number } \\
\text { of patients } \\
\text { before } \\
\text { ablation }\end{array}$ & $\begin{array}{l}\text { Transition } \\
\text { to the group 1 }\end{array}$ & $\begin{array}{l}\text { Transition } \\
\text { to the group 2 }\end{array}$ & $\begin{array}{l}\text { Transition } \\
\text { to the group 3 }\end{array}$ \\
\hline Group 1 & 10 & 21 & - & - & 2 \\
\hline Group 2 & 23 & 14 & 9 & - & - \\
\hline Group 3 & 7 & 5 & 4 & - & - \\
\hline
\end{tabular}

patients had a change in a angle towards the normalization of HEA position, they transferred to the group 1 from the group 2. In $5 \%(n=2)$ there was a change in $\mathrm{aF} Q R S$ angle with transition to the group 3.

Changes of aF QRS angle in patients with AF after RFA PVI have not been studied previously. Variety of aF QRS angles, we found in the early postoperative period with the HEA deviation to the right, can not be explained from the point of view of existing mechanisms known today, because it is acute, not long-term [6,10-12]. The possible cause of its change may be PVI during RFA. The evidence for this argument is the transitions of patients from one to another group after RFA, when their maximum number is concentrated in the group 1 from the group 2 .

The obtained data also shows the diagnostic significance of aF QRS angle against values of its projections on the planes due to the significant change in the first relatively non-significant changes of the others after the RFA PVI in the acute postoperative period.

\section{Conclusions}

1. In patients with $A F$ in the acute postoperative period a significant transformation of aF QRS angle distribution from bimodal with maxima in the groups 1 and 2 in a single-modal one occurs with a maximum displacement to the right in the region of the HEA normal position.

2. For the HEA position in patients with AF after RFA $\mathrm{PVI}$ the resultant vector $\mathrm{aF} Q R S$ angle is informative but its projections on the planes are low informative.

Prospects for further research. It seems advisable to compare $\mathrm{aF} Q R S$ angle changes with the atrial vector changes in patients with AF undergoing RFA PVI.

Funding

The investigation was carried out within the framework of the research work "Pharmacological and intervention approaches to the therapy of patients with cardiac rhythm disturbances and arterial hypertension" (state registration number 0116U000973).

Conflicts of Interest: authors have no conflict of interest to declare. Конфлікт інтересів: віАсутній.

Information about authors:

Rybchynskyi S. V., MD, Assistant of the Department of Internal Medicine, V. N. Karazin Kharkiv National University, Ukraine. Brynza M. S., MD, PhD, Associate Professor of the Department of Internal Medicine, Medical Faculty, V. N. Karazin Kharkiv National University, Ukraine.

Volkov D. Ye., MD, PhD, Senior Scientific Researcher, Head of the Department, SI "Zaitsev V. T. Institute of General and Urgent Surgery NAMS of Ukraine”, Kharkiv, Ukraine. Yabluchanskyi M. I., MD, PhD, DSc, Professor, Medical Faculty, Head of the Department of Internal Medicine, V. N. Karazin Kharkiv National University, Ukraine.
Відомості про авторів:

Рибчинський С. В., асистент каф. внутрішньої медицини, Харківський національний університет імені В. Н. Каразіна, україна.

Бринза М. С., канА. меА. наук, Аоцент каф. внутрішньої медицини, меАичний факультет, Харківський національний університет імені В. Н. Каразіна, Україна.

Волков А. Є., канА. меА. наук, старший науковий співробітник, зав. відАілення, АУ «нститут загальної та невіАкладної хірургії імені В. Т. Зайцева НАМН України", м. Харків. Яблучанський М. І., А-р меА. наук, професор, зав. каф. внутрішньої медицини, меАичний факультет, Харківський національний університет імені В. Н. Каразіна, україна.

\section{Сведения об авторах:}

Рыбчинский С. В., ассистент каф. внутренней медицины,

Харьковский национальный университет имени В. Н. Каразина, Украина.

Брынза М. С., канд. меА. наук, Аоцент каф. внутренней медицины, медицинский факультет, Харьковский национальный университет имени В. Н. Каразина, Украина.

Волков А. Е., канА. меА. наук, старший научный сотрудник, зав. отделением, ГУ «Институт общей и неотложной хирургии имени В. Т. Зайцева НАМН Украины", г. Харьков.

Яблучанский Н. И., А-р меА. наук, профессор, зав. каф. внутренней медицины, меАицинский факультет, Харьковский национальный университет имени В. Н. Каразина, Украина.

Надійшла Ао редакції / Received: 10.01.2018

Після Аоопрацювання / Revised: 31.01.2018

Прийнято Ао Аруку / Accepted: 02.02.2018

\section{References}

[1] Sychov, O. S. (2012). Fibrillyaciya predserdij. Sovremennye podkhody k lecheniyu i profilaktike oslozhnenij u pacientov s soputstvuyushche patologiej serdca [Atrial fibrillation. Modern approaches to the treatment and prevention of complications in patients with concomitant pathology of the heart]. Ukrainskyi medychnyi chasopys, 6(86), 54-57. [in Russian]

[2] Kirchhof, P., Benussi, S., Kotecha, D., Ahlsson, A., Atar, D., Casadei, B., et al. (2016). 2016 ESC Guidelines for the management of atrial fibrillation developed in collaboration with EACTS. European Heart Journal, 37(38), 2893-2962. doi: 10.1093/eurheartj/ehw210.

[3] January, C., Wann, L., Alpert, J., Calkins, H., Cigarroa, J., Cleveland, J., et al. (2014). 2014 AHA/ACC/HRS Guideline for the Management of Patients With Atrial Fibrillation. Journal of the American College of Cardiology, 64(21), e1-e76.

[4] Prystowsky, E., Padanilam, B., \& Fogel, R. (2015). Treatment of Atria Fibrillation. JAMA, 314(3), 278.

[5] Wecke, L., Poçi, D., Schwieler, J., Johansson, B., Edvardsson, N Lundahl, G., \& Bergfeldt, L. (2013). Vectorcardiography shows cardiac memory and repolarization heterogeneity after ablation of accessory pathways not apparent on ECG. International Journal of Cardiology, 166(1), 152-157. doi: 10.1016/j.ijcard.2011.10.106.

[6] Houghton, A., \& Gray, D. (2014). Making sense of the ECG: a hands-on guide. Boca Raton: CRC Press.

[7] Yamashita, S., Date, T., Yamane, T., Matsuo, S., Ito, K., Narui, R., et al. (2011). Noninvasive vectorcardiographic evaluation of pulmonary vein-atrial reconnection after pulmonary vein isolation for atrial fibrillation. Heart Rhythm, 8(9), 1398-1403. doi: 10.1016/j.hrthm.2011.04.023

[8] Mikio, S., Yasuya, I., Takahisa, S., Naoya, T., Haruo, H., Teruo, I., et al. (2000). Comparison of Vectorcardiographic and 12-lead Electrocardiographic Detections of Abnormalities in Repolarization Properties due to Preexcitation in Patients with Wolff-Parkinson-White Syndrome Japanese Heart Journal, 41(3), 295-312.

[9] Karayiannides, S., Lundman, P., Friberg, L., \& Norhammar, A. (2018) High overall cardiovascular risk and mortality in patients with atrial fibrillation and diabetes: A nationwide report. Diabetes and Vascular Disease Research, 15(1), 31-38. doi: 10.1177/1479164117735013.

[10] Voronenko, O. S., Brynza, M. S., Volkov, D. E., Lopin, D. O., Martynenko, O. V., \& Yabluchansky, M. I. (2016). Heart electrical axis a angle values distribution in patients, undergoing permanent pacemaker implantation Journal of V. N. Karazin' KhNU. Series «Medicine», 31(1), 32-36.

[11] Pérez Riera, A., Uchida, A., Filho, C., Meneghini, A., Ferreira, C. Schapacknik, E., et al. (2007). Significance of Vectorcardiogram in the Cardiological Diagnosis of the 21st Century. Clinical Cardiology 30(7), 319-323. doi: 10.1002/clc.14.

[12] Chugh, S. N. (2014). Textbook of clinical electrocardiography. New Delhi. 